Coluccia, D., Dabić, M., Del Giudice, M., Fontana, S., \& Solimene, S. (2019). R\&D innovation indicator and its effects on the market. An empirical assessment from a financial perspective. Journal of Business Research. https://doi.org/10.1016/j.jbusres.2019.04.015

\title{
R\&D innovation indicator and its effects on the market: An empirical assessment from a financial perspective
}

\section{Abstract}

We propose an alternative firm-level measure for innovation activities — R\&D elasticity — and we analyse its effects on the Tobin's Q of listed companies on the Euronext 100 Index. We find that R\&D elasticity is positively related to market appreciation by stakeholder investors. Moreover, we analyse the role of default risk in the relationship between innovation activities and market value, and find that firms' default probabilities are negatively related to Tobin's Q. These findings are supported by OLS regressions, wherein Tobin's Q is regressed on R\&D elasticity, five-year default probability, and controls such as ESG voluntary disclosure. These results further the research aimed at developing a conceptual framework for integrating at a policy level the R\&D elasticity indicator as a type of innovation disclosure among the non-financial disclosures released by companies.

\section{Keywords}

Innovation elasticity - market value - default risk - disclosure - stakeholder 


\section{R\&D innovation indicator and its effects on the market: An empirical assessment from a financial perspective}

\section{Introduction}

Firms vary in how rapidly they undertake innovation processes and communicate them to their stakeholders' plethora (Perrigot et al., 2012). Advances in open innovation processes flow from substantial changes that have occurred in the operating environment.

It is widely accepted that technology and technological advances are a key component of innovation and economic growth (Grossman and Helpman, 1994). Organizations want to access, develop, absorb, or commercialize new technologies; thus, the pace of technological change has increased dramatically.

Organizational knowledge and the role of knowledge workers have acquired increasing importance (Savino, 2009), and the diffusion of knowledge has become the key resource in post-industrial societies (Bell, 1973). Due to the speed and intensity of change, more information is needed, and this information must be acquired at a progressively faster pace. In addition, amid the dramatic changes in operating environments, periods of market equilibrium are becoming shorter. In the absence of lengthy periods of market stability, it is becoming increasingly difficult to maintain traditional fixed positions of competitive advantage (D’Aveni, 1994). Traditionally, investment in R\&D has been regarded as a key strategy for achieving high technological potential and thus innovation and economic growth (Trajtenberg 1990). However, it is becoming difficult to hold on to an advantage long enough to pay the costs of significant internal R\&D investment or for those processes to generate innovations at the speed required by markets. Since strategies must be constantly revisited and reformulated, an exclusive reliance on internal R\&D and closed innovation processes no longer makes strategic sense (Gürtler and Lindemann, 2013). Under the assumption that $R \& D$ is fundamental for innovation, several considerations ensue.

First, traditional firm-level accounting metrics no longer fully represent the shareholder value perceived by investors. Since value creation is hard to measure, new indicators are needed to define which drivers lead to efficient financial performance in a multi-stakeholder collaboration environment (Reypens et al., 2016). 
Second, since we know that innovation, generated through R\&D expenditure, is one of the most important elements of firms' competitive advantage, innovation research should also reconsider organizational processes in order to explore the management practices, processes, structures, and tools (known collectively as 'innovation management', or IM) used by firms to generate and communicate new ideas and make them successful in the market.

Third, it is also important from a research perspective to examine how stakeholders perceive their share of value coming from $R \& D$ information released by managers, under the assumption that $R \& D$ activities are considered a source of agency problems between insiders (managers) and outsiders (stakeholders) (Cheng, 2004).

For those reasons, studies should analyse the tools through which firms strive to maintain and increase firm performance, value creation and perception, and competitive advantage.

We start with the consideration that managers can use R\&D activities to foster stakeholder engagement, as these activities are being used as MI tools and as metrics for increased economic performance. We use a regression model to test if the disclosure of the R\&D elasticity indicator can affect firms' market appreciation for a sample of 57 European listed companies on the Euronext 100 Index. To validate the model, we use traditional control variables that the literature has linked to firm performance. We also compare R\&D indicator information to traditional voluntary ESG CSR disclosure in terms of their contribution to firm performance.

This study makes several contributions to the literature. First, to the best of our knowledge, it is the first to study the influence of alternative drivers of innovation on value creation for stakeholders within the field of IM. According to Volberda et al. (2013), IM is under-researched largely because of its metrics, processes, and structures. At a strategic level, managers could reconsider this metric as an innovation strategy tool for the resourcing of innovation activities (Adams et al., 2006). The long-term benefits are even greater, since such a new metric also allows companies to link changes in R\&D strategy, practices, and processes more 
closely to profitability and value. Further, it allows managers to define the innovation expenditure level that is optimal for enhancing firm growth.

Second, few studies on this topic have been performed in the European context. The extant research focuses on US and UK firms due to the salience and liquidity of their financial markets. Only a few comparative studies have examined firms in continental Europe (Hall and Oriani, 2006; Josheski and Sopova, 2013) due to the information opacity, less-developed financial markets, and limited number of listed firms in those countries (Duqui et al., 2011).

Third, by introducing a new metric for innovation productivity (Knott, 2012), which we propose can affect firms' performance (Tobin's q), we contribute to communication research in the literature on finance and management. Our indicator represents an item that firms can communicate to the market so as to enable it to estimate the effectiveness of their R\&D investment relative to the competition, and to determine how changes in R\&D spending affects the firm's bottom line and, most importantly, market value. Consistent with prior research that found a positive relationship between firm value and accounting information on intangibles ( $\mathrm{Gu}$ and $\mathrm{Li}, 2003)$, our measure of $\mathrm{R} \& \mathrm{D}$ disclosure is also useful for investors who demand greater disclosure, particularly when financial accounting is less-informative or in a high-uncertainty environments. Investors rely on accounting information in their decision making. Our study furthers our understanding regarding if, and to what extent, current flaws in accounting rules for R\&D and intangible assets prejudice this class of stakeholder.

At a policy level, this study finds that managers should improve their disclosure on non-financial items, in compliance with European legislation about non-financial information (UE/Dir 95/2014). Such a disclosure should reflect firms' market value in ways that financial outcomes cannot ( $\mathrm{Gu}$ and $\mathrm{Li}, 2003$ ) and could be considered value-relevant at the firm level. According to Lev and Zarowin (1999), who empirically demonstrated that firms with higher levels of R\&D spending generate less-informative earnings, when earnings are less informationally useful, disclosures on innovation, particularly those concerning the firm's 
long-term strategies or non-financial leading indicators, can provide investors with more value-relevant information.

Finally, as for the European context, little investigations have been performed so far. Existing contributions are strongly focused on USA and UK firms due to the relevance and liquidity of the financial markets of these countries. There are few comparative studies (Hall and Oriani, 2006; Josheski and Sopova, 2013) for Continental European countries, as a result of the opacity of information, the less developed financial markets, and the limited number of listed firms (Duqui et al, 2011).

In the next section, we provide theoretical background and review the literature. Section 3 develops our hypothesis and our model. Section 4 describes the study's methodology. Section 5 presents our results. Section 6 discusses the results. Finally, section 7 presents conclusions and outlines the study's implications.

\section{Conceptual Background}

\subsection{Management innovation versus technological innovation}

For years, studies on innovation have been focusing on its technological aspects. However, the field of innovation deals with other aspects, such as business model innovation, service innovation, and MI (Gallego et al., 2013; Mol and Birkinshaw, 2009; Vassakis et al. (2018).). The term 'management innovation' is relatively recent, although the concept was discussed before it appeared through terms such as ‘organizational innovation' and 'administrative innovation' (Daft, 1978; Damanpour, 1987; Kimberly \& Evanisko, 1981). Innovation in management principles and processes is attracting growing academic interest. Recent studies have analysed it both together with technological innovation (Camisón \& VillarLopez, 2014; Ganter and Hecker, 2013; Khanagha et al., 2013) and independently. Birkinshaw, Hamel, and Mol (2008) provided an interesting discussion on MI, which led to other papers on this topic (Cerne, Jaklic, \& Skerlavaj, 2013; Khanagha et al., 2013; Mol \& Birkinshaw, 2009; Vaccaro et al., 2012; Walker et al., 2011) that will probably provide the basis for many future research opportunities. 
Management innovation has characteristics that distinguish it from product innovation. On the one hand, management innovations are typically introduced to improve the efficiency of the organization's internal administrative processes, while innovation in goods or services tries to satisfy external demands (Walker et al., 2011). On the other hand, the non-technological nature of MI means that the firm's managers play a more important role in its development and adoption than technicians or researchers do (Ganter and Hecker, 2013). According to Birkinshaw and Mol (2006), due to its nature, MI constitutes a very rare attribute and a precious source of competitive advantage developed at an organizational level that lies in a firm's practices, structures, and techniques and constitutes a unique characteristic for every firm that can generate it.

We adopt the perspective on MI offered by Birkinshaw et al. (2008), whereby MI increases efficiency in the use of inputs and the effectiveness of organizational processes. This in turn enhances the firm's economic growth as well as the market value of their equity and of their equipment. The relationship between MI and technological innovation seems to lie in the fact that MI serves as an antecedent of technological innovation, as it consists of processes and attitudes that enhance access to successful technology and the speed of that access. It can be argued that MI and technological innovation are interdependent in the sense that one influences the other (Ganther and Hecker, 2013). The main consequences and outcomes of innovation management processes, structures, and techniques are profitability, growth, productivity, and capabilities (Gebauer, 2011; Mol and Birkinshaw, 2009; Walker et al., 2011). Our intention is to verify the relationship between the ability of management to make and to communicate innovation and the market appreciation of their firms. Nevertheless, MI also involves the satisfaction of the whole plethora of stakeholders (involving customer satisfaction, employee fidelity, and sustainability).

Despite the recent research interest in innovation management, the holistic framework in which management and technological innovation can interact has yet to be identified. Many scholars have addressed this topic (Altıntas et al., 2017; Chiesa et al., 1996; Volberda et al., 2012, 2013; Wolfe, 1994). 
Their attempts have aimed at operationalizing measures of IM, but no generalized consensus has emerged in the literature, since most studies have focused on the technology context (Ernst, 2002). Understanding how ideas can be created and turned into marketable products requires us to measure MI (Adams et al., 2006).

\subsection{Innovation measurement}

It is very hard to measure, benchmark, or quantify the processes that incorporate innovation. Thus, firms and scholars have focused on measuring innovation inputs and outputs in terms of factors such as spending, brands, licenses, patents, number of new products, and R\&D intensity. Expenditure on R\&D is used extensively as a proxy for innovation, as it improves the capability to develop new products and processes and improve existing ones. Our intention is not to build up a holistic and theoretical framework (though this would help provide managers with a way to evaluate their innovation processes). However, our comparative analysis furthers the research because it moves away from extant metrics for specific inputs to a more complete and global metric for the estimation of efficiency/productivity in firms' use of investment, particularly in R\&D.

As mentioned, the accounting and management literature acknowledges that accounting financial performance measures (such as ROI and ROE) do not fully reflect the real value of a firm. For this reason, other variables should be considered in the analysis of firm value creation. Our study aims to clarify which innovation variables can affect the market appreciation of the value created by firms.

Regarding the relationship between innovation and value creation, the literature has empirically demonstrated a relationship between $R \& D$ expenditure or patents, as a measure of innovation activities and firm performance using various testing techniques. Some scholars (Chandy et al., 2006; Duran et al., 2015) use conversion rate and the ability of firms to convert input to innovative output (i.e., technology into performance; Capon et al., 1990; Greve, 2003; Hull and Rothenberg, 2008; Durand et al., 2008; Mc Williams and Siegel, 2000; Rota et al., 2017). Other scholars have examined the relationship between 
innovation, as measured by new product introduction, and firm performance or market value/market share (Girotra et al., 2007; Thornill, 2006; Zhao, 2009). Others have studied how innovation affects current and future firm valuations (Cohen et al., 2013).

The weakness of this research stream is that the studies rely on patents or similar data (e.g. citation data), which do not represent the only drivers of R\&D activity because firms can choose which innovations they want to patent and can choose to patent innovations only under certain circumstances. Strategy\&, a business unit within PriceWaterhouseCoopers, has been publishing an annual report on the top 1000 most innovative companies in the world for over 12 years. In that time, it has found no statistically significant relationship between traditional R\&D spending and sustained financial performance. Its findings apply to total $R \& D$ spending, as well as to $R \& D$ spending as a percentage of revenues. Spending on R\&D is not related to growth in sales or profits, increases in market capitalization, or shareholder returns.

Table 1 summarizes the relevant literature on innovation measurement, focusing on technology or market value indicators concerned with the concept of innovation performance (Denti, 2013).

\section{TABLE 1}

Finally, several scholars have recently used new subjective and qualitative assessment measures (Martin, 2012), including innovative work behaviour (De Jong and Den Hartog, 2010), organizational innovation (García-Morales et al., 2008; Xie et al., 2010) and cultural intelligence (Elenkov and Manev, 2009). In relation to our analysis, traditional measures of $R \& D$ investment conversion rates, such as ratios about patents or $R \& D$ spending and sales as well as $R \& D$ intensity measures (ratio between $R \& D$ expenditure and added value), are only loosely linked to profits or market value. Knott and Vieregger (2018) provided economic empirical evidence confirming the theory that, as R\&D expenditure increases, the firm's market value decreases when firms exceed their optimum R\&D spending. Such a conclusion makes it difficult for executives to know whether they are spending as much (or as little) as they should, let alone whether they should improve how they spend (Adams et al., 2006). 


\subsubsection{R\&D Returns}

The question of how to measure R\&D returns is not new. It has its roots in several empirical/econometric studies on $R \& D$ and productivity that attempted to assess the contribution of $R \& D$ to economic growth and productivity at the firm level. The analytical framework used in these studies is the Cobb-Douglas production function, in which $\mathrm{R} \& \mathrm{D}$ is integrated as an input of the production function as are other explanatory variables (e.g. labour and capital). Thus, the residual growth factor in production that is not accounted for by the usual inputs (e.g. labour, capital, intermediate inputs) is assumed to be the product of R\&D that produces technical change (Hall et al., 2009). Mairesse and Sassenou provided in 1991 a clear overview of the surveys on this topic, divided into cross-sectional and time-series estimates of R\&D elasticity, starting with the pioneering work of Minasian (1969) and Griliches (1973) on elasticities of R\&D capital.

In line with the abovementioned considerations and to answer the call for a measurement of innovation, we consider the R\&D elasticity coefficient ( $R \& D$ firm-specific output elasticity of $R \& D$ ) from the traditional Cobb-Douglas production function as a metric for innovation, under the assumption that innovation has several inputs whose contributions have to be measured (in Brown and Svenson [1988], innovation is disaggregated into people, equipment, facilities, funds, and inputs). Further, we consider the R\&D elasticity as a new metric for innovative activities from a managerial and financial perspective. This methodology is not new, but we develop it by adding $R \& D$ elasticity (or the ' $R \& D$ innovation indicator') in a regression model as a predictor of the market value of firms, or market capitalization. Therefore, R\&D elasticity can be considered a tool by which management can disseminate innovation to the market, as a kind of voluntary non-financial disclosure.

Regarding the innovation measuring process, Cooper et al. (2018) provide empirical evidence that indicators like the productivity and efficiency of $R \& D$ spending have effects on firm value much greater than those of traditional intangible proxies such as patents. Moreover, R\&D productivity is more 
appropriate than traditional measures for asset pricing and corporate finance at the firm level because it is in line with the general assumption that boards can manage firm innovation through strategic decisions about the right level of R\&D spending and other investments, which will turn into firm value. Moreover, most firms engaging in $\mathrm{R} \& \mathrm{D}$ do not patent their innovations, which are traditionally considered a measure of innovation. For Cooper et al. (2018), this indicator could be a new and interesting measure for innovation, which managers can use to predict firm value, as well as a new variable in innovation studies. According to Knott (2012), this indicator can be used as a new metric for R\&D productivity, which could lead to many long-term benefits, since it allows companies to turn R\&D practices and strategies into profitability and market value. Its contribution to firm revenues can be estimated by adding to the economic capital (spending on property, plant, and equipment) and labour productivity function another input represented by $R \& D$ efficiency. This will lead to a better understanding of how much one unit of R\&S will result in in firm revenue (for the estimation of R\&D elasticity, see section 4 below).

\subsection{Innovation disclosure to financial market and firm value.}

In today's knowledge economy, firms have opened their innovation processes to external third parties to mitigate their risk exposure on financial markets. The innovation network theory sheds light on how firms may realize innovation processes in a multi-stakeholder perspective to foster sustainable growth (Barney, 1991). Recently, the management literature (Dhanaraj and Parkhe, 2006; Perks and Jefferey, 2006) has investigated the way in which firms should manage these different interests to produce financial results and innovativeness and to communicate the outcomes to the market.

The question of how R\&D investments are disclosed to the market and subsequently affect overall firm performance is of considerable interest to economists and researchers investigating ways of making the market aware of innovation processes. Starting with the seminal work of Griliches (1981), several empirical researchers have used market value as a proxy for the evaluation of R\&D expenditure (Oriani, and Sobrero, 2003). Few studies have been performed on $R \& D$ disclosure and its impact on the market, while a number 
of studies have dealt with R\&D disclosure (Ding et al., 2004; Zéghal et al., 2007). To the best of our knowledge, only Nekhili et al. (2016) examine the impact of voluntary R\&D disclosure on the market value of firms within the European context. Since previous empirical studies show a positive relationship between increased R\&D expenditure and firm value (Hall and Oriani, 2006; Healy and Palepu, 1993; Khasawneh and Dasouqi, 2017) and since others find a positive association between voluntary information and firm value (Banghøj and Plenborg, 2008), it is expected that R\&D disclosure positively influences the market value of companies.

We perform a complementary empirical assessment by focusing on the European context and on a new, specific metric for R\&D disclosure, which could integrate firms' traditional forms of voluntary disclosure. This study provides new insight into the relationship between innovation and disclosure from a stakeholder perspective. Stakeholder theory deals with the long-term concern of firms to manage stakeholder expectations in order to legitimize their position in the market and gain profits. The stakeholder view of strategy integrates both the resource-based view and market-based view and adds socio-political concerns. The relevant literature has focused on the way external stakeholders may bring their knowledge to companies in the so called 'open innovation processes' to turn ideas and knowledge taken from third parties into new products and services in a collaborative network (Desouza et al., 2008; Dzikowski, 2016; Fidel et al., 2015; Fossas-Olalla et al., 2015; Wu, 2014). Our contribution is to integrate disclosure, innovation, and value creation to determine if the disclosure released by management about firms' innovation activities and R\&D's contribution to firm growth affects the short-term value perceptions of investors, one of the most important stakeholder groups. To that end, we measure the relationship between R\&D elasticity (a measure for innovation, to be disclosed) and firms' market value to examine if the financial market is able to appreciate the R\&D activity disclosed by managers under the assumption of the efficient market hypothesis. Since the literature has found a clear association between a firm's market value and R\&D investment (Bosworth et al., 2000; Cockburn and Griliches, 1987; Hall and Oriani, 2006) while controlling for other 
firm assets, we expect that the financial market will appreciate the value of the firm that has undertaken the investment.

In our model, we consider as stakeholders the financial lenders or investors as representatives of the market complex environment for innovative companies (Grossman, 1981). In the traditional shareholder view of the firm (Friedman, 1970), the sole responsibility of a business is to increase profits for its owners. A focus on short-term strategy and greater risk taking are just two of the dangers inherent in this view. According to the stakeholder theory, a company has to meet wider and longer-term expectations from different groups of stakeholders, other than just shareholders. A stakeholder is defined as any person/group that can affect or be affected by the actions of a business (Freeman, 1984). The incompatibility between the short- and long-term views can be solved by analysing the enlightened shareholder value (Millon, 2010) - by matching the aims of these two different perspectives (shareholder and stakeholder theory), considering that a firm can generate shareholder value while also having regard to the long-term external impacts of its wealth generation. While future earnings are increasingly uncertain, value can be created through different strategies that consider the long-term perspective of growth via investments in R\&D.

Given that future earnings are growing ever more uncertain and that financial measures are becoming less predictive or informative, firms should increase their voluntary non-financial disclosure to satisfy investors' information demands and help them assess their firm value. According to Gu and Li (2003, p. 145), from an accounting measurement perspective, the lack of informativeness in the earnings of high-technology firms is likely related to a mismatch between revenues and expenses under the expensing rule of R\&D due to an accounting GAAP mismatch. According to Zégal and Maaloul (2011), voluntary disclosure may be a solution to the negative consequences of the non-recognition of intangibles in financial statements. When the R\&D investment rate changes over time, reported earnings based on immediate expensing will differ materially from economic earnings based on $R \& D$ capitalization. $R \& D$ investments are immediately expensed pursuant to GAAP rules even though, in modern economies, these investments are the most important long-run drivers of value at the firm level. This distortion in the accounting measurement process 
is expected to adversely affect the usefulness of earnings information. Consistent with this view, Lev and Zarowin (1999) find that firms with greater increases in $R \& D$ spending rates have less-informative earnings. More recently, Lev and Gu (2016) have shown that US high-technology firms have been increasing their market capitalization over the last 10 years, while their financial statements report great losses. R\&D activities are uncertain because markets and professional stakeholders can hardly predict their outcomes and because of the lags between investments and their realisation. Amir, Lev, and Sougiannis (2003) have argued that spending on R\&D intangibles biases analysts' short-term forecasts. Thus, disclosure on $R \& D$, especially on the capability to spend on $R \& D$ and technology, can be useful to analysts and to the market in general.

Investors are important to firm performance. Their decision making relies on financial reports, and accounting rules do not reflect real firm growth. Thus, the market must be made aware of how firms invest in long-term intangibles, despite the GAAP lack in reporting.

To address these issues, we consider the R\&D efficiency/elasticity indicator as a new measure for innovation disclosure. It is less costly and reflects the ability of managers to spend on $\mathrm{R} \& \mathrm{D}$, as it assesses management's capability to translate R\&D spending into production and applied technology, and ultimately into revenues.

Our hypothesis is that an R\&D elasticity disclosure indicator can affect investment decision-making processes because it is more efficient in explaining firms' market appreciation (Knott, 2003) than other non-mandatory and non-financial forms of disclosure.

Consistent with the recent introduction of the ground-breaking EU Directive on the disclosure of nonfinancial and diversity information (Directive 2014/95/EU), we wonder from a policy perspective whether innovation activity and behaviour can be integrated with non-financial information for release to the market. In that sense, it is important to investigate how firms communicate their ability to spend effectively and efficiently. The elasticity of $R \& D$ spending we consider is much more meaningful than simple $R \& D$ spending; such information can positively affect economic performance as measured by Tobin's Q. 
According to Srivastava, Shervani, and Fahey (1998), R\&D intensity is a significant driver of firm performance through market-based measures.

\section{$3 \quad$ Model Hypothesis}

Corporate finance researchers use Tobin's $Q$ to proxy for firms' investment opportunities. In the value relevance and asset pricing literature, the Q-ratio - the ratio between the market's valuation of the financial book value and the cost of replacing assets (tangible and intangible) — has been used to explain a wide variety of phenomena (Cockburn and Griliches, 1987; Megna and Klock, 1993) by relating the Q ratio to intangible capital. The Q ratio's appropriateness depends on the theoretical assumptions made. At a firm level, Tobin's Q explains tangible and intangible investments equally well, and it explains total investment even better (Peters and Taylor, 2016).

In our model, the dependent variable is Tobin's Q, which represents the judgement of the financial market on a company's value; the critical explicative variable is ' $R \& D$ elasticity' ( $R \& D E$ ). This coefficient measures not only R\&D investments but also their effectiveness and efficiency through the contribution of R\&D expenses (input) to revenues (output). In particular, we test if innovation produces positive effects on firm value. We thus hypothesise as follows:

$H_{1}:$ The higher a firm's $R \& D$ elasticity, the higher its Tobin's $Q$.

\section{$4 \quad$ Methodology}

To test our hypothesis, we perform an OLS regression in which the dependent variable is the firm's market appreciation measured by Tobin's Q. The explanatory endogenous variable is R\&D elasticity (R\&DE), which is in our model a metric of firm disclosure related to the productivity of R\&D expenditure. We estimate it from the Cobb-Douglas production function. We seek to mediate the relationship between firms' market value and innovation to study the effect of voluntary disclosure on Tobin's Q. 
To control for this effect, we add several control variables that the literature usually relates to Tobin's Q. We integrate the ESG disclosure indicator, a common proxy for voluntary disclosure, into the model to verify what portion of firms' market value perceived by investors (shareholder value) is explained by the two variables (R\&D Elasticity and ESG Score). The literature has tested the positive relationship between the ESG score and data and Tobin's Q (e.g. Hillman and Keim, 2001; Waddock and Graves, 1997), and we expect that R\&D elasticity produces the same effect.

For control variables, we add firms' five-year probability of default. Firm performance on the market is dependent on risk exposure and uncertainty about future cash flows. We investigate the role of credit default risk (i.e. five-year default probability) following the consideration of Erickson and Jacobson (1992) of the positive effect of innovation on R\&D intensity and profitability over time, as well as that of D'Aveni and Ilinitch (1992). We find that lower default risk positively affects the market appreciation of firms' activity on the financial market.

\subsection{Sample selection}

We collected the data for a homogenous sample composed of 57 listed companies on the Euronext 100 index, the blue chip index of the pan-European exchange. It is one of two pan-European stock indices (PanEuropean indices) launched in October 2000 by Euronext. It has a base of 31.12.1999 = 1000 and is composed of the main and most-treated actions on Euronext. Each stock must trade more than $20 \%$ of its issued shares over the course of the rolling one-year analysis period. It is reviewed quarterly. The dimension of the selected index — which represents approximately $81 \%$ of the total capitalization of Euronext—allows us to generalize the obtained results to the European context as a whole.

We selected companies belonging to the index on December 31, 2016. For each firm, we collected all the data required for the regressions. At the end of the data collection process, we excluded companies with missing data, thus obtaining a stable sample of 57 companies, distributed across several countries (see Table 2) and sectors (see Table 3). 
TABLE 2 AND TABLE 3

In contrast to previous studies, which focused on the US or the UK, we selected European listed companies that have rarely been investigated. In our sample, the country with the largest number of companies is France $(78.95 \%)$, followed by the Netherlands (14.04\%), Belgium (5.26\%), and Luxembourg (1.75\%). The industries with the largest number of companies are the following: chemicals (10.53\%), automobiles and parts $(10.53 \%)$, aerospace and defence $(8.77 \%)$, and software and computer services $(7.02 \%)$; together, these represent almost $50 \%$ of the sample.

\subsection{Dependent variable: Tobin's $Q$ in innovation context}

There is widespread agreement that firms need to accumulate specific innovation capabilities to survive and prosper in a knowledge-based economy, face new challenges, and attain high performance. In the knowledge economy, intangible assets such as $R \& D$ investments have a strong impact on the value creation of an enterprise (Zanda, 2012).

Regarding the relationship between innovation and firm performance, Zhang et al. (2014) argue that, although the importance of innovation is widely accepted (Andrew et al., 2007; Barsh et al., 2007), the results of studies on the link between innovation and performance remain inconclusive. The authors attribute this inconclusiveness to the limitations of existing innovation measures. The literature has studied the effects produced on firm productivity using $R \& D$ investment or $R \& D$ intensity — generally measured as the ratio between $R \& D$ expenses and total assets or total sales, or total value (Balasubramanian et al., 2010; Başgoze and Cem Sayin, 2013; Duqi et al., 2011; Halle and Mairesse, 1995), or as the number of patents (Feeny and Roger, 2003). The authors do not consider these measures adequate proxies for innovation activities due to their high failure rate.

Much of the literature has investigated the effects of innovation only on accounting measures such as sales (Lin and Chen, 2007; Thornhill, 2006), or on indicators such as ROI and ROS (Durand et al., 2008; Hendricks and Singhal, 2008; Hull and Rothenberg, 2008). Accounting-based measures of firm 
performance tend to ignore the contribution of intangibles and R\&D to performance dimensions such as strategic flexibility and intangible value. Despite the limits of accounting rules, the market seems to appreciate innovation activity and rewards companies that pay attention to innovation (Lev and Gu, 2016). Few studies have used Tobin's Q to understand investors' reactions to innovation activities (Cho and Pucik, 2005; Liao et al., 2015; Rubera and Droge, 2013; Zhang et al., 2014). Hall et al. (2009) point out that market value, or Tobin's Q, is an important measure for firms, as it relates the current financial value of a firm to its underlying assets, including knowledge or R\&D assets. We chose Tobin's Q (Bontis, 1998) as a proxy with which to estimate the firms' market value. Tobin's Q, as highlighted by Wright (2004), is estimated as follows:

$$
Q=(\text { market } \text { value of equity+liabilities }) /(\text { total assets })
$$

\subsection{Explicative variables}

As mentioned, we seek to test if innovation produces effects on firm value as measured by Tobin's Q. Our explicative variable is 'R\&D elasticity' (R\&DE). This coefficient measures not only R\&D investments but also their effectiveness and efficiency through the contribution of $R \& D$ expenses (input) to revenues (output). To estimate R\&D elasticity, we used the method developed by Knott (2008, 2012). Starting from the known economic formula for the production function, Knott considered as inputs not only capital and labour but also R\&D investments (Knott, 2012):

$$
Y=K^{\alpha} L^{\beta} R \& D^{\gamma}
$$

where output (Y) is represented by the company's sales, and the inputs are capital (K), labour (L), and R\&D expenses. In this function, the exponents measure the productivity of each input in generating the output (Knott, 2012); thus, they measure the elasticity of the revenue on each input.

To estimate the exponents of the function, we applied a multiple regression. We collected several years' worth of data from our sample firms on R\&D expenses, property investments, employee costs, and revenues covering 2006 to 2016. We applied a multiple regression wherein, for each company, the dependent variable 
is revenues, and the explicative variables are property investments (capital), cost of employees (labour), and R\&D expenses. For each company, we applied five OLS regressions for five periods (2012 to 2016). Each regression contains (following Knott) a data observation period of seven years. For instance, the R\&D elasticity for 2012 (the first period we analysed) is produced from data covering 2006 to 2012. To obtain the R\&DE trend, we simply drop the earliest year, add a new year, and repeat the process (Knott, 2017). The function is as follows (Knott, 2008):

$$
\operatorname{Ln} S=\left(\beta_{0}+\beta_{1}\right)+\left(\beta_{1}+\beta_{1 i}\right) \times \operatorname{Ln} K_{i t}+\left(\beta_{2}+\beta_{2 i}\right) \times \operatorname{Ln} L_{i t}+\left(\beta_{3}+\beta_{3 i}\right) \times \operatorname{LnR\& D_{it-1}}
$$

where $\mathrm{S}$ is sales, $\mathrm{K}$ is property investments, $\mathrm{L}$ is the cost of employees, and $\mathrm{R} \& \mathrm{D}$ is the lag amount of $\mathrm{R} \& \mathrm{D}$ expenses for the previous year.

The result of the regression allowed us to obtain the R\&D elasticity (R\&DE), which is equal to the beta coefficient of the R\&D expenses variable. As mentioned, this indicator represents the explicative variable of our model, which verifies if innovation management could positively affect firms' financial performance.

\subsection{Control variables}

a) ESG score

Several studies have shown the benefits of CSR disclosure. The research has highlighted that CSR disclosure improves firm image and reputation, a firm's capacity to attract the best employees (Cormier et al., 2011), profitability (Chen et al., 2015; Singh, 2014; Yusoff et al., 2013), and financial analysts' forecast (Cormier and Magnan, 2014; Dhaliwal et al., 2012). Studies have also found a positive and significant relationship between CSR disclosure and firm value (Cormier et al., 2009; Habbash, 2017; Qui et al., 2016). The ESG score represents judgements about a firm's environmental, social, and governance disclosure. We collected data for this indicator from the Bloomberg database, which covers 120 environmental, social, and governance indicators. Bloomberg evaluates companies annually, collecting public ESG information disclosed by companies through corporate social responsibility (CSR) or sustainability reports, annual reports and websites, other public sources, as well as through company direct contact. 


\section{b) Five-year probability of default}

Another control variable is default probability, which in our hypothesis negatively affects firm value (the higher the probability, the lower the firm's value). Companies with a high default probability are risky and are not appreciated by the financial market. To financial investors, default risk affects stock returns, as a high risk of default is linked to low stock returns because it compromises a firm's ability to pay its obligations with future cash flows (Cornell and Shapiro, 1987). According to Sun and Price (2016), a good credit risk rating, especially a long-term one, can improve a firm's chances of starting long-term operational investment activities, such as those related to innovation. Under the assumption of the resource-based theory, we seek to understand if managers' R\&D investment decisions are not only efficient but are also appropriate for the firm's economic returns and performance on the financial market, especially since longterm default risk is a predictor of the firm's future cash flows. In our regression, we selected data on fiveyear default probability from the Bloomberg database to consider a medium-duration timeframe within which our variables can produce effects on firm value. Bloomberg's default risk dataset provides an independent evaluation of a company's credit health using market data (share price and volatility), fundamental data, and cutting-edge quantitative models. The five-year probability of default is calculated using the Bloomberg Issuer Default Risk Model.

\section{c) Firm size}

Firm size is an important control variable that affects firm performance: larger firms may have greater capabilities, better skills, and more credibility, which may have a positive impact on the financial market. Several researchers have tested the positive relationship between firm size and firm value (Connolly and Hirshey, 2005; Feeny and Rogers, 2003; Gómez-González et al., 2012).

Regarding the relationship between size and innovation, previous studies have focused on the positive effect firm size has on R\&D expenditures: the firm's propensity to invest in R\&D has been found to be positively associated with its size (Dosi, 1988; Fisher and Temin, 1973). Therefore, it is expected that the relationship 
between size and innovation is positive and significant (Acs and Audretsch, 1988; Moohammad et al., 2014; Pla-Barber and Alegre, 2007). However, it is natural to expect that R\&D is undertaken by small and medium-sized enterprises (SMEs) as well and to assume that economies of scale operate in R\&D expenditures. The relationship between firm size and R\&D activities is to be seen from this perspective, since many scholars have recently demonstrated that a large number of small firms engage in innovative activities. This is especially true for high-tech firms (Shefer and Frenke, 2005).

Our study investigates the degree of the association between firm size and elasticity of investments in R\&D activities, relying on the consideration that the $R \& D$ spending of small firms is more efficient. For company size, we used the natural logarithm of total assets to reduce variability, in line with major studies on the subject (Gray et al., 1995; Reverte, 2009; Stanny and Ely, 2008).

\section{d) Firm age}

Several empirical studies (Chaudhuri et al., 2016; García-Quevedo et al., 2014; Solís and Rubio, 2016; Usman et al., 2017) in the value creation research stream have shown that new firms typically need time to accommodate and improve their internal capabilities. This means that they need time to turn capabilities into value. It can thus be hypothesized that there is a positive association between innovation and firm age. Recently, however, Coad et al. (2016) have shed light on how the nature of innovative activity and performance changes with firm age. Their results show that the R\&D investments of young firms are more likely to result in faster growth rates than the R\&D investments of incumbent and older firms. Very similar results can be seen in the Italian analysis by Cuccunelli (2018). Cooper et al. (2018) empirically demonstrated that the elasticity of R\&D is higher in young firms using a sample of US firms. In our model, firm age is measured as the number of years since the first IPO (Initial Public Offering; Liu and Anbumozhi, 2009; Zeng et al., 2012).

e) Leverage

The literature examining the relationship between market value and leverage has found mixed results used various measures of financial structure soundness. Studies have found both positive and negative significant 
relationships (Chadha and Sharma, 2015; Chaudhuri et al., 2016; Gómez-González et al., 2012; Malighetti et al., 2011; Pranati, 2017; Szewczyk et al., 1996; Usman et al., 2017).

We consider that equilibrium, a good balance of financial-structure decisions, is vital to the short- and longterm development of a company. Bhagat and Welch (1995) find that R\&D spending and the ratio of assets to liabilities in the previous year have significant and positive correlations and that firms' financial resources affect their attitude to R\&D activities. According to Kim and Park (2012) and Lai et al. (2015), investing in $R \& D$ activities requires financial resources; hence, opportunities to invest in $R \& D$ activities increase when a firm has capital structures that provide financial autonomy. We examine the relationship between R\&D, innovation, and firms' market value from this point of view.

Regarding the financial situation, we selected leverage and measured the ratio between total financial debt and equity (Cormier et al., 2005; Déjean and Martinez, 2009; Malone et al., 1993; Tri Setyorini and Ishak, 2012).

\section{f) Profitability}

Profitability is an important control variable that affects firm performance: firms with high profitability are appreciated by the financial market. The literature has found a positive and significant relationship between Tobin's Q and accounting performance as measured by ROI (Landsman and Shapiro, 1995). Some studies show that ROI is a significant measure of firm performance, but it is necessary to also consider other information that is not recognized and not accounted for in the balance sheet (Arcelus et al., 2005). Regarding the relationship between profitability and innovation, we can assume that companies with high levels of profitability have more financial resources with which to invest in innovation activity. We measure firm profitability as return on investment, equal to the ratio between EBIT and operative capital.

\subsection{Statistical model}


To test our hypothesis, we perform a multivariate regression analysis by relating the dependent variable (Tobin's Q) to the explanatory variables (R\&D elasticity and default risk). We also include the other control variables identified in the prior section. The regression can be summarized in the following multivariate model:

$$
\text { Tobin's } Q=\alpha+\beta_{1} R \& D E+\beta_{2} E S G+\beta_{3} \ln A+\beta_{4} A g e+\beta_{5} L e v+\beta_{6} R O I+\beta_{7} P D \_5 Y
$$

where Tobin's Q is our dependent variable; R\&DE is R\&D elasticity; ESG is the CSR disclosure indicator; LnA is the natural logarithm of total assets; Age is the company's age; Lev is the leverage; ROI is the return on investment; and PD_5Y is the five-year default probability.

\section{Analysis and results}

\subsection{Descriptive statistics}

Before performing a multivariate analysis to test the hypothesis, we calculated the descriptive statistics of the dependent and independent variables (see Table 4) and the correlation matrix (see Table 5).

\section{TABLE 4}

The analysis of the descriptive statistics indicates that the average of Tobin's Q shows an increasing value from 1.410 in 2012 to 1.569 in 2016.

The descriptive statistics highlight that the average levels of R\&D elasticity appear stable over time at a level of 0.05 ; this value indicates that a firm's revenue will increase by $5 \%$ if its R\&D spending increases by $1 \%$. Analysing the other statistics reveals a slight improvement in the median, from 0.023 in 2012 to 0.026 in 2016, and in the maximum value, from 0.334 in 2012 to 0.366 in 2016.

The average leverage level decreases from 2012 to 2016 (4.4 in 2012 and 4.2 in 2016), probably due to the European recovery after the financial crisis; the average asset level increases during the same period (9.90 
in 2012 and 10.12 in 2016), and ROI follows the same trend, with a stable increase during each year $(6.61 \%$ in 2012 and $8.67 \%$ in 2016). Finally, the average default probability level appears stable, at 0.01 .

The correlation matrix (see Table 5) shows that Tobin's Q, in line with our expectations, has a positive and statistically significant relation with the R\&DE variable and a negative and statistically significant relation with Probability of default. This means that the lower the probability of default, the greater the firm's value, consistent with the theory. Moreover, the correlation matrix does not show a statistically significant relationship between the ESG score and Tobin's Q. It is important to stress the correlation between Probability of default and several other explanatory variables such as Assets, Age, and R\&DE. The Probability of default has a negative statistically significant relation with all three explanatory variables. This seems to confirm that, in Europe, young companies have lower capacities to innovate and higher rates of early failure (García-Quevedo et al., 2014), as well as that larger and older firms are more firmly established than younger and smaller ones. It is well-known that a substantial proportion of new firms go bankrupt within a few years of foundation (Agarwal and Audretsch, 2001). Finally, the matrix shows that, as R\&D elasticity grows, default probability decreases.

\section{TABLE 5}

\subsection{Multiple regression}

Before running the regressions, we checked for multicollinearity among the explicative variables using VIF. We also used robust standard error clustered at the firm level (HAC). We also verified the sample's normality in relation to its size using a Jarque-Bera test. Regressions were conducted using the ordinary least squares model. The Breusch-Pagan test verified that this model is preferable to the random-effects panel model, and the Hausman test verified that a random-effects panel model is preferable to a fixedeffects panel model. 
We estimated a multiple regression to analyse the effect of $R \& D E$ on firm value. Table 6 reports the regression results of the equation where Tobin's Q is regressed on R\&DE and the controls.

\section{TABLE 6}

The goodness-of-fit of the proposed model is presented in Table 6 . The regression returns a high $\mathrm{R}^{2}$ value (0.435). In addition, the small difference between the $\mathrm{R}^{2}$ and adj $\mathrm{R}^{2}$ values $(0.421)$ demonstrates the adequacy of the number of explanatory variables considered in the model. It should also be noted that the p-values (F) attest to the significance of the model as a whole (i.e. all variables simultaneously). It is appropriate to focus on the variables that led to statistically significant results regarding what is asserted by theories and empirical verification.

The regression supports our hypothesis and highlights a positive and significant relationship between Tobin's Q and R\&D elasticity; the coefficient of regression is positive and significant. This result is consistent with the literature, as several studies have found a positive relationship between firm value and innovation (Cho and Pucik, 2005; Liao et al., 2015; Rubera and Droge, 2013; Zhang et al., 2014).

In line with our expectations, the relationship between Tobin's $Q$ and default probability is significant and negative: as the default probability increases, market value tends to decrease.

As shown in Table 6, all the control variables except for ESG and leverage exhibit significant coefficients $(\mathrm{p}$-value $\leq 0.10)$

According to McWilliams and Siegel (2000), this result should not be surprising because it could depend on the introduction among the explicative variables of an R\&D measure. The authors found that many firms that actively engage in CSR are also making complementary strategic investments in R\&D. This makes it difficult to isolate the impact of CSR on firm value without simultaneously controlling for R\&D.

In line with our expectations, size has a negative and significant relationship with firm value. Many scholars have demonstrated in recent years that a large number of small firms are engaging in innovative activities, 
especially high-tech firms (Shefer and Frenke, 2005). Therefore, we can conclude that the financial market appreciates small sizes in firms because they imply innovation activity.

The regression returns a negative highly significant coefficient on age $(<0.01)$ : the financial market seems to appreciate younger companies. These results support our hypothesis that young companies tend to innovate because they expect greater benefits from R\&D activity despite the risk (Coad et al., 2016; Cucculelli, 2018).

As we expected, ROI has a positive and significant coefficient: more-profitable companies are appreciated by the market and have a higher Tobin's Q. This conclusion confirms that ROI plays a central role in the relationship between innovation and a firm's market value.

\section{Discussion}

In this study, we analysed the effect on firm value of $R \& D$ productivity for a sample of firms listed on Euronext 100 from 2012 to 2016. Most expenditures on R\&D are, by their very nature, sunk costs (Stiglitz, 1987), and most companies calculate their target $R \& D$ spending as a percentage of their sales. Unfortunately, this approach does not lead to optimal R\&D productivity. That is why we followed Knott's approach (2008). The results confirm a positive and statistically significant effect with regard to firm value as measured by Tobin's Q. It seems that the market appreciates firms' R\&D productivity and that an efficient management of R\&D costs can also reduce a firm's distress risk. According to the so-called 'Schumpeterian hypothesis', firms' propensity to invest in R\&D should be positively correlated with their size. As numerous studies have pointed out, larger firms are not affected by liquidity constraints since they enjoy easier access to external finance and larger internal funds via cumulated profits (García-Quevedo et al., 2014). Small and medium-sized enterprises, which generally have fewer funds than large companies have, need to invest in innovation more efficiently (Shefer and Frenke, 2005); this is consistent with our results (i.e. that size has a negative and significant relationship with firm value). We consider financial 
lenders or investors as stakeholders, as they are representative of the market complex environment for innovative companies. Therefore, they are a privileged audience to which firms address their disclosure about innovation and their ways of turning it into financial performance. Scholars have suggested that firms have incentives to disclose information that helps investors assess firm value. In particular, the market can be influenced by information asymmetries between firms and stakeholders. These asymmetries depend on the fact that a firm has a better understanding of the potential success and structure of the R\&D project and thus that the marketplace for financing innovative assets could be characterized as a typical 'lemons market problem' (Akerlof, 1970).

The research on the link between $R \& D$ activity and market value has generally asserted that $R \& D$ is costly, provides long-term returns, and increases short-term financial risk. There is a generally low appreciation for future cash flows derived from $R \& D$ activity in the short-term. Future cash flow risk might affect the capacity of a firm to pay its debts and increase the probability of default. For this reason, there is a widespread consensus that investment in high R\&D spending is not beneficial to firm performance. Thus, short-term investors are unlikely to invest in R\&D-spending firms (Lu and Huang, 2009). Following Zhou and Pan (2018), who conclude that innovation can reduce stock price collapse at a financial level, we test the role of default probability in firm value (Tobin's Q). We adopt Zhou and Pan's conclusion about their tests, which confirm that the effect on risk of innovation is more obvious for small enterprises. Their study confirms, a fortiori, that R\&D investment significantly reduces the risk of a firm's stock price collapse. Hsu et al. (2015) conclude that default probabilities are negatively related to R\&D output (as measured by patent portfolios) and that innovative firms have lower realized excess returns (which are a measure of financial market volatility). In our study, the correlation matrix (see Table 5) shows a negative relationship between default risk (as measured by five-year default probability) and R\&D elasticity. This result is consistent with the conclusion of the above authors.

We also examined the relationship between innovation and disclosure. We added to the model the traditional ESG score to verify what portion of the market value perceived by investors is explained by 
R\&D elasticity and the ESG score. Our results show that R\&D elasticity has a significant effect on Tobin's Q, while the ESG score has no significant effect.

In our results, contrary to expectations, CSR disclosure does not seem to influence firm value. In other words, we find a substitution effect between R\&DE and the ESG score. We argue that more in-depth information on R\&D costs and innovation should be disseminated by firms to their stakeholders, particularly since the EU has set a clear course toward greater business transparency and accountability for non-financial issues.

\section{Conclusions}

This study examined the market appreciation of R\&D elasticity expenditure in the European context. To our knowledge, it is the first study to do so.

Our results (in sections 5 and 6) could stimulate future research on this topic by overcoming its challenges from theoretical and policy perspectives, particularly those emanating from our premises. Future management studies could, for instance, suggest alternative drivers of financial performance based on new metrics for innovation activities, such as innovation productivity/elasticity. It would also be worthwhile seeking to understand how managers could integrate alternative MI tools into strategies for improving financial performance. Moreover, given that R\&DE has a positive effect on Tobin's Q, managers could integrate this measure into a strategy for communicating their long-term innovation activities to investors. The R\&DE indicator allows managers to mitigate agency problems by engaging in stakeholder engagement - by changing the investors' decision process from a short-term to a long-term view.

From a business perspective, one question that could contribute to the accounting and finance literature needs to be explored. Is it the duty of managers to disclose their firm's innovation activities and efficiency levels to the market in order to affect the firm-value relevance of this information? Since we found that investors positively value R\&D efficiency and since accounting rules do not allow the highlighting of these results, it could be efficient at a policy level to enter this information on the balance sheet, at least among 
the voluntary information disclosed in it. Therefore, future studies could attempt to clarify if innovation activity and behaviour can be integrated among the non-financial information released to the market. Companies will increasingly 'run at a loss', under a misleading GAAP parameter, if current obsolete accounting rules do not catch up with the reality of today's markets. The real losers are the investors who rely on GAAP-based financial reports. All high-tech and science-based firms report losses just because they invest in future growth.

The challenge is to encourage standard-setters to change the current accounting gap in order to capitalize on the future benefits of innovation activities. In this sense, an R\&DE indicator could be a profitable piece of information and would assist in fundamental tasks such as estimating the private rate of return of investments in $R \& D$, evaluating the social rate of return, and estimating the real value of a firm. 


\section{Reference}

Acs, Z. J., \& Audretsch, D. B. (1988). Innovation in large and small firms: an empirical analysis. American Economic Review, 78(4), 678-690.

Acs, Z. J., \& Audretsch, D. B. (1990). Innovation and small firms. Boston: Mit Press.

Adams, R., Bessant, J., \& Phelps, R. (2006). Innovation management measurement: A review. International Journal of Management Reviews, 8(1), 21-47.

Agarwal, R., \& Audretsch D. B. (2001). Does Entry Size Matter? The Impact of the Life Cycle and Technology on Firm Survival. Journal of Industrial Economics, 49(1), 21-43.

Akerlof, G. A. (1970). The market for "lemons": quality uncertainty and the market mechanism. The Quarterly Journal of Economics, 84(3), 488-500.

Altıntas, F., Kurtulmusoglu F.B., Altintas, M.H., Kaufmann, H.R., \& Alkibay, S. (2017). The mediating effects of adaptive selling and commitment on the relationship between management control and sales performance. EuroMed Journal of Business, 12(2), 221-240, https://doi.org/10.1108/EMJB-12-2016-0037

Amir, E., Lev, B., \& Sougiannis, T. (2003). Do financial analysts get intangibles? European Accounting Review, 12(4), 635-659.

Andrew, J. P., Sirkin, H., Haanas, K., \& Michael, D. C. (2007). Innovation 2007: a BCG senior management survey, The Boston Consulting Group. https://www.bcg.com/documents/file15063.pdf.

Arcelus, F. J., Mitra, D., \& Srinivasan, G. (2005). On the incidence of deferred taxes, intangibles and nonlinearities in the relationship between Tobin's Q and ROI. Journal of Economics and Business, 57(2), 165185.

Artz, K. W., Norman, P. M., Hatfield, D. E., \& Cardinal, L. B. (2010). A Longitudinal Study of the Impact of R\&D, Patents, and Product Innovation on Firm Performance. Journal of Product Innovation and Management, 27(5), 725-740.

Axtell, C. M., Holman, D. J., Unsworth, K. L., \& Wall, T. D. (2000). Shopfloor innovation: Facilitating the suggestion and implementation of ideas. Journal of Occupational and Organizational Psychology, 73, 265285.

Balasubramanian, N., Black, B. S., \& Khanna, V. (2010). The relation between firm-level corporate governance and market value: A case study of India. Emerging Markets Review, 11(4), 319-340.

Banghøj J., \& Plenborg T. (2008). Value relevance of voluntary disclosure in the annual report. Accounting and Finance, 48(2), 159-180.

Barney, J. (1991). Firm resources and sustained competitive advantage. Journal of Management, 17(1), 99120. 
Barsh, J., Capozzi, M., \& Mendonca, L. (2007). How companies approach innovation: a Mckinsey global survey. McKinsey

quarterly. https://www.elkarbide.com/sites/default/files/MCKINSEY\%20INNOVACI\%C3\%93N.pdf.

Başgoze1, P., \& Cem Sayin, H. (2013). The effect of R\&D expenditure (investments) on firm value: case of Istanbul stock exchange. Journal of Business Economics and Finance, 2(3), 5-12.

Bell D. (1973). Post-Industrial Society. New York: Free Press.

Bhagat, S., \& Welch, I. (1995). Corporate Research and Development Investments: International Comparisons. Journal of Accounting and Economics, 19(2-3), 443-470.

Birkinshaw, J., \& Mol, M. (2006). How management innovation happens. MIT Sloan Management Review, 47(4), 81-88.

Birkinshaw, J., Hamel, G., \& Mol, M. (2008). Management innovation. Academy of Management Review, $33(4), 825-845$.

Bontis, N. (1998). Intellectual capital: an exploratory study that develops measures and models. Management Decision, 36(2), 63-76.

Brown, M. G., \& Svenson, R. A. (1988). Measuring R\&D productivity. Research Technology Management, 41(6), 30-35.

Calantonea, R. J., Cavusgila, S. T., \& Zhao, Y. (2002). Learning orientation, firm innovation capability, and firm performance. Industrial Marketing Management, 31(6), 515- 524.

Camisón, C., \& Villar-López, A. (2014). Organizational innovation as an enabler of technological innovation capabilities and firm performance. Journal of Business Research, 67(1), 2891-2902.

Chandy R., Hopstaken B., Narasimhan O., \& Prabhu J.(2006). From Invention to Innovation: Conversion Ability in Product Development. Journal of Marketing Research, 43(3), 494-508.

Capon, N., Farley, J. U., \& Hoenig, S. (1990). Determinants of financial performance: a meta-analysis. Management science, 36(10), 1143-1159.

Cerne M., Jaklic M., \& Škerlavaj M. (2013). Management Innovation in focus: the role of knowledge exchange, organizational size, and IT system development and utilization. European Management Review, 10, 153-166.

Chadha, S., \& Sharma, A. K., (2015). Capital structure and firm performance: empirical evidence from India. Vision (09722629), 19(4), 295-302.

Chaudhuri, K., Kumbhakar, S. C., \& Sundaram, L. (2016). Estimation of firm performance from a MIMIC model. European Journal of Operational Research, .255(1), 298-307.

Chen, L., Feldmann, A., \& Tang, O. (2015). The relationship between disclosures of corporate social performance and financial performance: evidences from GRI reports in manufacturing industry. International Journal of Production Economics, 170, 445-456. 
Cheng S. (2004). R\&D Expenditures and CEO Compensation. Accounting Review, 79(2), 305-328.

Chiesa, V., Coughlan, P., \& Voss, A. (1996). Development of a technical innovation audit. Journal of Product Innovation Management, 13(2), 105-136.

Cho, H. J., \& Pucik, V. (2005). Relationship between innovativeness, quality, growth, profitability, and market value. Strategic Management Journal, 26(6), 555-575.

Coad, A., Segarra, A., \& Teruel, M. (2016). Innovation and firm growth: Does firm age play a role? Research Policy, 45, 387-400.

Cockburn, I., \& Griliches, Z. (1987). Industry effects and appropriability measures in the stock market's valuation of R\&D and patents. American Economic Review, 78(2), 419-423.

Cohen L., Diether K., \& Malloy C. (2013). Misvaluing innovation. Review of Financial Studies, 26(3), 635666.

Connolly, R. A., \& Hirschey, M. (2005). Firm size and the effect of R\&D on Tobin's Q. R\&D Management, $35(2), 217-223$.

Cooper-Searle, S., Livesey, F., \& Allwood, J. M. (2018). Why are material efficiency solutions a limited part of the climate policy agenda? An application of the multiple streams framework to UK policy on $\mathrm{CO} 2$ emissions from cars. Environmental Policy \& Governance, 28(1), 51-64.

Cormier, D., \& Magnan, M. (2014). The impact of social responsibility disclosure and governance on financial analysts' information environment. Corporate Governance: The International Journal of Effective Board Performance, 14(4), 467-484.

Cormier, D., Aerts, W., Ledoux, M. J., \& Magnan, M. (2009). Attributes of social and human capital. disclosure and information asymmetry between managers and investors. Canadian Journal of Administrative Sciences, published online in Wiley Interscience (www.interscience.wiley.com). https://onlinelibrary.wiley.com/doi/pdf/10.1002/cjas.89.

Cormier, S., Magnan, M. \& Van Velthoven, B. (2005). Environmental disclosure quality in large German companies: economic incentives, public pressures or institutional conditions? European Accounting Review, 14(1), 3-39.

Cornell, B., \& Shapiro, A. C. (1987). Corporate stakeholders and corporate finance. Financial Management, 16(1), 5-14.

Cucculelli, M. (2018). Firm age and the probability of product innovation. Do CEO tenure and product tenure matter? Journal of Evolutionary Economics, 28(1), 153-179.

Czarnitzki, D., \& Kraft, K. (2004). Firm leadership and innovative performance: evidence from seven EU countries. Small Business Economics, 22, 325-332.

D’Aveni, R.A. (1994). Hypercompetition: Managing the Dynamics of Strategic Maneuvering. New York: The Free Press. 
D'Aveni, R. A., \& Ilinitch, A. Y. (1992). Complex patterns of vertical integration in the forest products industry: Systematic and bankruptcy risks. Academy of Management Journal, 35(3), 96-625.

Daft, R. L. (1978). A dual-core model of organizational innovation. The Academy of Management Journal, 21(2), 193-210.

Damanpour, F. (1987). The adoption of technological, administrative and ancillary innovations: impact of organizational factors. Journal of Management, 13(4), 675-688.

de Jong, J., \& den Hartog, D. (2010). Measuring Innovative Work Behaviour. Creativity \& Innovation Management, 19(1), 23-36.

Déjean, F. \& Martinez, I. (2009). Environmental disclosure and the cost of equity: the French case. Accounting in Europe, 6(1), 57-80.

Denti, L. (2013). Measuring Innovation part 1: Frequently Used Indicators, Retrieved October 23, 2013 from Innovation Management. http://www.innovationmanagement.se/2013/02/15/measuring-innovationpart-1-frequently-used-indicators.

Desouza, K. C., Awazu, Y., Jha, S., Dombrowski, C., Papagari, S., Baloh P., \& Kim, J. Y. (2008). Customer-Driven Innovation. Research-Technology Management, 51(3), 35-44.

Dhaliwal D. S., Radhakrishnan S., Tsang A., \& Yang Y. G. (2012). Nonfinancial disclosure and analyst forecast accuracy: international evidence on corporate social responsibility disclosure. The Accounting Review, 87(3), 723-759.

Dhanarag, C., \& Parkhe, A. (2006). Orchestrating Innovation Networks. Academy of Management Review, 31(3), 659-669.

Ding Y, Entwistle G., \& Stolowy H. (2004). International differences in research and development reporting practices: a French and Canadian comparison. Advances in International Accounting, 17, 55-72. https://doi.org/10.1016/S0897-3660(04)17003-7.

Dosi, G. (1988). Sources, procedures and microeconomic effects of innovation. Journal of Economic Literature, 26(3), 1120-1171.

Duqi, A., Mirti, R., \& Torluccio, G. (2011). An analysis of the R\&D effect on stock returns for European listed firms. European Journal of Scientific Research, 58(4), 482-496.

Duran P., Kammerlander N., van Essen M., \& Zellweger T. (2015). Doing more with less: innovation input and output in family firms. Academy of Management Journal, 59(4), 7-76. https://www.alexandria.unisg.ch/244500/1/amj.2014.0424.full.pdf.

Durand, R., Bruyaka, O., \& Mangematin, V. (2008). Do science and money go together? The case of the French biotech industry. Strategic Management Journal, 29(12), 1281-1299.

Dzikowski, P. (2016). The Impact of spatial proximity to customers, suppliers and competitors on innovation activity in medium high and high technology industry in Poland. Contemporary Economy, 7(4), 107-117. 
Elenkov, D. S., \& Manev, I. M. (2009). Senior expatriate leadership's effects on innovation and the role of cultural intelligence. Journal of World Business, 44(4), 357-369.

Erickson, G., \& Jacobson, R. (1992). Gaining comparative advantage through discretionary expenditures: The returns to R\&D and advertising. Management Science, 38(9), 1264-1279.

Ernst, H. (2002). Success factors of new product development: a review of the empirical literature. International Journal of Management Reviews, 4(1), 1-40.

Ettlie, J. E., \& Reza, E. M. (1992). Organizational Integration and Process Innovation. Academy of Management Journal, 35(4), 795-827.

Feeny, S., \& Rogers, M. (2003). Innovation and performance: benchmarking Australian firms. The Australia Economic Review, 36(3), 253-264.

Fidel, P., Schlesinger, W., \& Cervera, A. (2015). Collaborating to innovate: Effects on customer knowledge management and performance. Journal of Business Research, 68 (7), 1426-1428.

Fisher, F. M., \& Temin, P. (1973). Returns to scale in research and development: what does the schumpeterian hypothesis imply? Journal of Political Economy, 81(1), 56-70.

Fossas-Olalla, M., Minguela-Rata, B., López-Sánchez, J. I., \& Fernández-Menéndez, J. (2015). Product innovation: When should suppliers begin to collaborate? Journal of Business Research, 68(7), 1404-1406.

Freeman, R.E. (1984). Strategic Management: A Stakeholder Approach. Boston: Pitman.

Friedman M. (1970). The Social Responsibility of Business is to Increase its Profits. The New York Times Magazine, September 13.

Gallego, J., Rubalcaba, L., \& Hipp, C. (2013). Services and organisational innovation: the right mix for value creation. Management Decision, 51(6), 1117-1134.

Ganter, A., \& Hecker, A. (2013). Deciphering antecedents of organizational innovation. Journal of Business Research, 66(5), 575-584.

García-Quevedo, J., Pellegrino, G., \& Vivarelli, M. (2014). R\&D drivers and age: are young firms different? Research Policy, 43(9), 1544-1556.

García-Morales, V., Matías-Reche, F., \& Hurtado-Torres, N. (2008). Influence of transformational leadership on organizational innovation and performance depending on the level of organizational learning in the pharmaceutical sector. Journal of Organizational Change Management, 21(2), 188-212.

Gebauer, H. (2011). Exploring the contribution of management innovation to the evolution of dynamic capabilities. Industrial Marketing Management, 40(8), 1238-1250.

Girotra, K., Terwiesch, C., \& Ulrich, K. T. (2007). Valuing R\&D projects in a portfolio: Evidence from the pharmaceutical industry. Management Science, 53(9), 1452-1466. 
Gómez-González, J. E., Rincon, C. E. L., \& Leiton Rodríguez, K. J. (2012). Does the use of foreign currency derivatives affect firms' market value? Evidence from Colombia. Emerging Market \& Trade, 48(4), 50-66.

Gray, R., Kouhy, R. \& Lavers, S. (1995). Corporate social and environmental reporting: a review of the literature and a longitudinal study of UK disclosure. Accounting, Auditing and Accountability Journal, 8(2), $47-77$.

Greve, H.R. (2003). A behavioral theory of R\&D expenditures and innovations: evidence from shipbuilding. Academy of Management Journal, 46(6), 685-702.

Griliches, Z. (1973). Research expenditures and growth accounting. In B. R. Williams (Eds.), Science and technology in economic growth (pp. 59-95). London: MacMillan.

Griliches, Z. (1981). Market value, R\&D, and patents. Economics Letters, 7(2) 183-187.

Grossman, S. J. (1981). The role of warranties and private disclosure about product quality. Journal of Law and Economics, 24, 461-483.

Grossman G. M., \& Helpman E. (1994). Endogenous innovation in the theory of growth. Journal of Economic Perspectives, 8(1), 23-44.

Groza, M. D., Locander, D. A., \& Howlett C. H. (2016). Linking thinking styles to sales performance: The importance of creativity and subjective knowledge. Journal of Business Research, 69(10), 4185-4193.

Gu, F., \& Li, J. Q. (2003). Disclosure of innovation activities by high-technology firms. Asia-Pacific Journal of Accounting \& Economics, 10(2), 143-172.

Gumusluoglu, L., \& Ilsev, A. (2009). Transformational leadership, creativity, and organizational innovation. Journal of Business Research, 62, 461-473.

Gürtler, M. R., \& Lindemann, U. (2013, August). Situative open innovation-A model for selecting the right external actors and involving them in an efficient way. In DS 75-3: Proceedings of the 19th International Conference on Engineering Design (ICED13) Design For Harmonies, Vol. 3: Design Organisation and Management, Seoul, Korea 19-22.08. 2013.

Habbash, M. (2017). Corporate social responsibility disclosure, financial performance and firm value: the case of Saudi Arabia. Journal of Administrative Sciences, 24(1), 81-105.

Hall, B. H. \& Mairesse, J. (1995). Exploring the relationship between R\&D and productivity in French manufacturing firms. Journal of Econometrics, 65(1), 263-293.

Hall B. H., \& Oriani R. (2006). Does the market value R\&D investment by European firms? Evidence from a panel of manufacturing firms in France, Germany, and Italy. International Journal of Industrial Organization, 24(5), 971-993.

Hall B. H., Thoma G., \& Torrisi S. (2007, October). The market value of patents and R\&D: Evidence from European firms. Academy of Management Annual Meeting Proceedings. 
Healy, P. M., \& Palepu K. (1993). The effect of firms' financial disclosure strategies on stock prices. Accounting Horizons, 7(1), 1-11.

Hendricks, K., \& Singhal, V. (2008). The effect of product introduction delays on operating performance. Management Science, 54(5), 878-892.

Hillman A. J., \& Keim, G. D. (2001). Shareholder value, stakeholder management, and social issues: What's the bottom line? Strategic Management Journal, 22(2), 125-139.

Hull, C., \& Rothenberg, S. (2008). Firm performance: The interactions of corporate social performance with innovation and industry differentiation. Strategic Management Journal, 29(7), 781-789.

Hsu, P. H., Lee, H. H., Liu, A. Z., \& Zhang Z. (2015). Corporate innovation, default risk, and bond pricing. Journal of Corporate Finance, 35, 329-344.

Josheski D., \& Magdinceva-Sopova M. (2013). Market value of the firms and R\&D investment: theoretical overview and empirical estimation for the panel of countries, paper No. 44094. https://mpra.ub.unimuenchen.de/44094/.

Jung, D. D., Wu, A., \& Chow, C. W. (2008). Towards understanding the direct and indirect effects of CEOs' transformational leadership on firm innovation. The Leadership Quarterly, 19(5), 582-594.

Kanagal, N. B. (2015). Innovation and product innovation in marketing strategy. Journal of Management and Marketing Research, 1-25. https://s3.amazonaws.com/academia.edu.documents/44945173/Innovation_and_product_innovation_in_ marketing_strategy.pdf?AWSAccessKeyId=AKIAIWOWYYGZ2Y53UL3A\&Expires=1523357731\&Sig nature=TgerFWpN89ng724YqFf\%2FK4roxNM\%3D\&response-contentdisposition=inline \%3B\%20filename\%3DInnovation_and_product_innovation_in_mar.pdf.

Karagouni, G. (2018). Production technologies and low-technology knowledge-intensive venturing. EuroMed Journal of Business, 13(1), 75-85.

Khanagha, S., Volberda, H. W., Sidhu, J. S., \& Oshri, I. (2013). Management innovation and adoption of emerging technologies: The case of cloud computing. European Management Review, 10(1), 51-67.

Khasawneh, A.Y., \& Dasouqi, Q.A. (2017). Sales nationality and debt financing impact on firm's performance and risk: Evidence from Jordanian companies. EuroMed Journal of Business, 12(1), 103-126, https://doi.org/10.1108/EMJB-05-2016-0015

Kim, H., \& Park, S. Y. (2012). The relation between cash holdings and R\&D expenditures according to ownership structure. Eurasian Business Review, 2(2), 25-42.

Kimberly, J. R. \& Evanisko, M. J. (1981). Organizational innovation: the influence of individual, organizational, and contextual factors on hospital adoption of technological and administrative innovations. The Academy of Management Journal, 24(4), 689-713.

Knott, A. M. (2003). The organizational routines factor market paradox. Strategic Management Journal, Special Issue, 24(10), 929-943. 
Knott, A. M. (2008). R\&D/Returns causality: absorptive capacity or organizational IQ. Management Science, 54(12), 2054-2067.

Knott, A. M. (2012). The Trillion-Dollar R\&D Fix. Harvard Business Review, 90(5), 76-82.

Knott, A. M. (2017). How innovation really works. Using the Trillion-Dollar R\&D fix to drive growth. New York: McGrawHill.

Knott, A. M. \& Vieregger, C. (2018). The Puzzle of Market Value from R\&D, Working paper. https://papers.ssrn.com/sol3/papers.cfm?abstract_id=2382885\&download=yes.

Lai, Y. L., Lin, F. J., \& Lin Y. H. (2015). Factors affecting firm's R\&D investment decisions. Journal of Business Research, 68(4), 840-844.

Landsman, W. R., \& Shapiro, A. C. (1995). Tobin's q and the relation between accounting ROI and economic return. Journal of Accounting, Auditing \& Finance, 10(1), 103-118.

Lev, B., \& Zarowin, P. (1999). The boundaries of financial reporting and how to extend them. Journal of Accounting Research, 37(2), 353-385.

Lev B., \& Sougiannis T. (1996). The capitalization, amortization, and value-relevance of R\&D. Journal of Accounting and Economics, 21(1), 107-138.

Lev, B., Sarath, B., \& Sougianis, T. (2005). R\&D reporting biases and their consequences. Contemporary Accounting Research, 22(4), 977-1026.

Lev B., \& Gu F. (2016). The end of accounting and the path forward for investors and managers. Hoboken, New Jersey: Wiley.

Liao, W. C., Tseng, C. C., \& Ho, M. H. C. (2015). The effects of integrating innovative resources on organizational performance: the moderating role of innovation life cycle. International Journal of Technology Management, 67(2, 3, 4), 215-244.

Lin, C. Y., \& Chen, M. Y. (2007). Does innovation lead to performance? An empirical study of SMEs in Taiwan. Management Research News, 30(2), 115-132.

Liu, X. \& Anbumozhi, V. (2009). Determinant factors of corporate environmental information disclosure: an empirical study of Chinese listed companies. Journal of Cleaner Production, 17(6), 593-600.

Lu, Y., \& Huang, C. (2009). Study on the Market Response of R\&D Expenditure in High-Tech Industry. Science \& Technology Progress and Policy, 8, 60-63.

Malighetti, P., Meoli, M., Paleari, S., \& Redondi, R. (2011). Value determinants in the aviation industry. Transportation Research Part E, 47(3), 359-370.

Malone, D., Fries, C. \& Jones, T. (1993). An empirical investigation of the extent of corporate financial disclosure in the oil and gas industry. Journal of Accounting, Auditing and Finance, 8, 249-279.

Mairesse J., \& Sassenou M. (1991). R\&D Productivity: A Survey of Econometric Studies at the Firm Level, working paper No. 3666. https://www.nber.org/papers/w3666. 
Martin, B. R. (2012). Innovation studies: challenging the boundaries. Lundvall Symposium on the Future of Innovation Studies, Aalborg University. http://sro.sussex.ac.uk/38701/.

McWilliams, A., \& Siegel, D. (2000). Corporate social responsibility and financial performance: Correlation or misspecification? Strategic Management Journal, 21(5), 603-609.

Megna, P., \& Klock, M. (1993). The Impact of Intangible Capital on Tobin's q in the Semiconductor Industry. The American Economic Review, 83(2), 265-269.

Millon D. (2010). Enlightened shareholder value, social responsibility, and the redefinition of corporate purpose without law. Washington \& Lee Legal Studies Paper No. 2010-11. http://www.csringreece.gr/files/research/CSR-1289998724.pdf.

Minasian J.R. (1969). Research and development, production functions, and rates of return. American Economic Review, 59(2), 80-85.

Mol, M. J., \& Birkinshaw, J. (2009). The sources of management innovation: When firms introduce new management practices. Journal of Business Research, 62(12), 1269-1280.

Moohammad, A. W., Nor'Aini, Y., \& Kamal, E. M. (2014). Influences of firm size, age and sector on innovation behaviour of construction consultancy services organizations in developing countries. Business Management Dynamics, 4(4), 01-09.

Naranjo-Valencia, J. C., Jiménez-Jiménez, D., \& Sanz-Valle, R. (2016). Studying the links between organizational culture, innovation, and performance in Spanish companies. Revista Latinoamericana de Psicología, 48(1), 30-41.

Nekhili, M., K. Hussainey, W. Cheffi, T. Chtioui, \& H. Tchakoute-Tchuigoua. (2016). R\&D narrative disclosure, corporate governance and market value: Evidence from France. Journal of Applied Business Research, 32(1), 1-16. https://doi.org/10.19030/jabr.v32i1.9527.

Oriani, R. \& Sobrero, M. (2003). Meta-Analytic Study of the relationship between R\&D investments and corporate value. In M. Calderini, P. Garrone, M. .Sobrero (Eds.), Corporate Governance, Market Structure and Innovation (pp. 177-199). Cheltenham, UK: Edward Elgar.

Perks, H., \& Jeffery, R. (2006). Global network configuration for innovation: a study of international fibre innovation. $R \& D$ Management, 36(1), 67-83.

Perrigot, R., Kacker, M., Basset, G., \& Cliquet, G. (2012). Antecedents of early adoption and use of social media networks for stakeholder communications: Evidence from franchising. Journal of Small Business Management, 50(4), 539-565.

Peters, R. H., \& Taylor, L. A. (2017). Intangible Capital and the Investment-q Relation. Journal of Financial Economics, 123(2), 251-272.

Pla-Barber, J., \& Alegre, J. (2007). Analysing the link between export intensity, innovation and firm size in a science-based industry. International Business Review, 16(3), 275-293.

Pranati M., (2017). Board size and firm performance in India. Journal of Management, 14(1), 19-30. 
Qiu Y., Shaukat A., \& Tharyan R. (2016). Environmental and social disclosures: Link with corporate financial performance. The British Accounting Review, 48(1), 102-116.

Reverte, C. (2009). Determinants of corporate social responsibility disclosure ratings by Spanish listed firms'. Journal of Business Ethics, 88(2), 351-366.

Reypens, C., Lievens, A., \& Blazevic, V. (2016). Leveraging value in multi-stakeholder innovation networks: A process framework for value co-creation and capture. Industrial Marketing Management, 56, 40-50.

Rota, M., Schettino, F., \& Spinesi, L. (2017). Key inventors, teams and firm performance: The Italian case. Structural Change and Economic Dynamics, 42,13-25.

Rubera, G., \& Droge, C. (2013). Technology versus design innovation's effects on sales and Tobin's Q: the moderating role of branding strategy. Journal of Production and Innovation Management, 30(3), 448464.

Savino, D. M. (2009). The role of technology as an enabler in job redesign. Journal of Technology Management \& Innovation, 4(3), 14-23.

Shefer, D., \& Frenke, A. (2005). R\&D, firm size and innovation: an empirical analysis. Technovation, $25(1), 25-32$.

Singh S. (2014). Impact of corporate social responsibility disclosure on the financial performance of firms in UK, Master Thesis Business Administration - Financial

Management.https://essay.utwente.nl/65014/1/Singh_MA_MB.pdf.

Solís R. F., \& Rubio S.F. (2016). Innovación Tecnológica en Empresas Chilenas: un Estudio Empírico Basado en Patentes. Journal of Technology Management \& Innovation, 11(4), 56-64.

Srivastava R. K., Shervani T. A., \& Fahey L. (1998). Market-based assets and shareholder value: a framework for analysis. Journal of Marketing, 62, 2-18.

Stanny, E. \& Ely, K. (2008). Corporate environmental disclosures about the effects of climate change. Corporate Social Responsibility and Environmental Management, 15(6), 338-348.

Stiglitz, J. E. (1987). Technological Change, Sunk Costs and Competition. Brookings Papers on Economic Activity, 3, 883-937.

Sun, W. \& Price, J. M. (2016). Implications of marketing capability and research and development intensity on firm default risk. Journal of Marketing Management, 32(1-2), 179-206.

Szewczyk, S. H., Tsetsekos, G. P., \& Zantout, Z. (1996). The valuation of corporate R\&D expenditure: evidence form investment opportunities and free cash flow. Financial Management, 25(1), 105-110.

Thornhill, S. (2006). Knowledge, innovation and firm performance in high- and low-technology regimes. Journal of Business Venturing, 21(5), 687-703. 
Trajtenberg M. (1990). A penny for your quotes: patent citations and the value of innovations. Journal of Economics, 21(1), 172-187.

Tri Setyorini, C. \& Ishak, Z. (2012). Corporate social and environmental disclosure: a positive accounting theory view point. International Journal of Business and Social Science, 3, 152-162.

Usman, M., Shaique, M., Khan, S., Shaikh, R., \& Baig, N. (2017). Impact of R\&D investment on firm performance and firm value: evidence from developed nations. Revista de Gestão, Finanças $e$ Contabilidade, 7(2), 302-321.

Vaccaro, I. G., Jansen, J. J. P., Van den Boschand, F. A. J., \& Volberda, H. W. (2012). Management innovation and leadership: The moderating role of organizational size. Journal of Management Studies, $49(1), 28-51$.

Vassakis, K., Sakka, G., \& Lemonakis, C. (2018). Demystification of the glass ceiling phenomenon: Gender stereotyping and successful managers' personality traits in Greece. EuroMed Journal of Business, 13(1), 2 19, https://doi.org/10.1108/EMJB-06-2017-0023

Volberda, H. W., Oshri, I., \& Mom, J. M. (2012). Technology transfer: The practice and the profession. Technology Analysis \& Strategic Management, 24(9), 863-869.

Volberda, H. W., Van Den Bosch, F. A. J., \& Heij, C. V. (2013). Management Innovation: Management as Fertile Ground for Innovation. European Management Review, 10(1), 1-15.

Waddock S., \& Graves S. (1997). The corporate social performance- financial performance link. Strategic Management Journal, 18(4), 303-319.

Walker, R. M., Damanpour, F., \& Devece, C. A. (2011). Management innovation and organizational performance: The mediating effect of performance management. Journal of Public Administration Research and Theory, 21(2), 367-386.

Wang, G., \& Miao, C. F. (2015). Effects of sales force market orientation on creativity, innovation implementation, and sales performance. Journal of Business Research, 68(11), 2374-2382.

West, M. A., Borrill, C. S., Dawson, J. F., Brodbeck, F., Shapiro, D. A., \& Haward B. (2003). Leadership clarity and team innovation in health care, The Leadership Quarterly, 14(4-5), 393-410.

Wolfe, R. A. (1994). Organizational innovation: review, critique and suggested research directions. Journal of Management Studies, 31(3), 405-431.

Wright, H. (2004). Measures of stock market value and returns for the U.S. nonfinancial corporate sector, 1900-2002. Review of Income and Wealth, 50(4), 561-584.

Wu, J. (2014). Cooperation with competitors and product innovation: Moderating effects of technological capability and alliances with universities. Industrial Marketing Management, 43(2), 199-209.

Xie, H., Liu, C., \& Chen, C. (2010). Relationships among market orientation, learning orientation, organizational innovation and organizational performance: An empirical study in the Pearl River Delta region of China. Frontiers of Business Research in China, 1 (2), 222-253. 
Yusoff, H., Mohamad, S. S., \& Darus, F. (2013). The Influence of CSR Disclosure Structure on Corporate Financial Performance: Evidence from Stakeholders' Perspectives. Procedia Economics and Finance, 7, $213-220$.

Zanda G. (2012), Corporate management in a knowledge-based economy. London: Palgrave Macmillan.

Zéghal D., \& Maaloul A. (2011). The accounting treatment of intangibles - A critical review of the literature Accounting Forum, 35(4), 262-274.

Zhang, G. P., Yu, J., \& Xia, Y. (2014). The payback of effective innovation programs: empirical evidence from firms that have won innovation awards. Production and Operations Management, 23(8), 1401-1420.

Zhao, X. (2009). Technological innovation and acquisitions. Management Science, 55(7), 1170-1183.

Zeghal D., Mouelhi R., \& Louati H. (2007). An analysis of the determinants of research \& development voluntary disclosure by canadian firms. The Irish Accounting Review, 4(2), 61-89.

Zeng, S. X., Xu, X. D., Yin, H. T. \& Tam, C. M. (2012). Factors that drive Chinese listed companies in voluntary disclosure of environmental information. Journal of Business Ethics, 109, 309-321.

Zhou, Z., \& Pan, D (2018). Can corporate innovation restrain the stock price crash risk? Journal of Financial Risk Management, 7, 39-54. 


\section{Tables}

Table 1

Measure of innovation.

\section{Measures of innovation}

New products or product improvements

Patents or patent citations

Invention disclosures or suggestions

Process innovations

Ratio of sales of new products to total sales

Sales force performance and capacity

Ratio of sales of new products to R\&D expenditures

Total R\&D spending

Number of employees in R\&D

New markets entered

\section{Literature}

Naranjo-Valencia et al. (2016)

Jung et al. (2008)

Axtell et al. (2000); Gu and Li (2003)

Ettlie and Reza (1992); West et al. (2003)

Czarnitzki and Kraft (2004)

Wang and Miao (2015)

Gumusluoglu and Ilsev (2009); Groza, Locander, Howlett (2016)

García-Morales et al. (2008); Artz, Norman, Hatfield and Cardinal (2010)

Calantonea et al. (2002); García-Morales et al. (2008)

Kanagal, N.B. (2015), Innovation and product innovation in marketing strategy, Journal of Management and Marketing Research, Volume 18, 1-25; Elenkov \& Manev (2009) 


\section{Table 2}

Sample selection: classification of companies by countries

\begin{tabular}{lcc}
\hline COUNTRY & $\#$ & $\mathbf{\%}$ \\
\hline Belgium & 3 & $5,26 \%$ \\
France & 45 & $78,95 \%$ \\
Luxemburg & 1 & $1,75 \%$ \\
Netherlands & 8 & $14,04 \%$ \\
\hline Total & 57 & $100,00 \%$ \\
\hline
\end{tabular}

\section{Table 3}

Sample selection: classification of companies by business industry

\begin{tabular}{lcc}
\hline BUSINESS INDUSTRY & $\#$ & $\%$ \\
\hline Basic Materials - Chemicals & 6 & $10,53 \%$ \\
Basic Materials - Industrial Metals \& mining & 1 & $1,75 \%$ \\
Consumer Goods - Automobilies \& Parts & 6 & $10,53 \%$ \\
Consumer Goods - Beverage & 1 & $1,75 \%$ \\
Consumer Goods - Personal Goods & 4 & $7,02 \%$ \\
Consumer Goods- Food Producers & 1 & $1,75 \%$ \\
Consumer Goods - Leisure Goods & 1 & $1,75 \%$ \\
Consumer Goods-Durable hausehold products & 1 & $1,75 \%$ \\
Costumer Services- Food \& Drug Retailers & 1 & $1,75 \%$ \\
Consumer Service -Media & 2 & $3,51 \%$ \\
Costumer Services - Travel e Leisure & 1 & $1,75 \%$ \\
Financials - Banks & 2 & $3,51 \%$ \\
Financials - Financial Service & 1 & $1,75 \%$ \\
Health care - Health Care Equipment \& services & 3 & $5,26 \%$ \\
Health care - Pharmaceutical \& Biotecology & 3 & $5,26 \%$ \\
Industrials - Aerospace e Defence & 5 & $8,77 \%$ \\
Industrials - Construction \& Materials & 2 & $3,51 \%$ \\
Industrials - Electronic \& Electrical Equipement & 2 & $3,51 \%$ \\
Industrials - Engineering & 1 & $1,75 \%$ \\
Oil e Gas & 1 & $1,75 \%$ \\
Technology- Software e computer services & 4 & $7,02 \%$ \\
Technology- Tecology hardware e equipment & 3 & $5,26 \%$ \\
Telecomunications - Fixed Line & 1 & $1,75 \%$ \\
telecomunications & 4 & $7,02 \%$ \\
Utilities & 57 & $100 \%$ \\
\hline Total & & \\
\hline & & \\
& &
\end{tabular}


Table 4

Descriptive statistics

\begin{tabular}{|c|c|c|c|c|c|c|c|}
\hline Variable & Mean & Median & Min & Max & Std.Dev. & Skewness & Kurtosis \\
\hline \multicolumn{8}{|l|}{2012} \\
\hline Tobin'sQ & 1,4097 & 1,2423 & 0,7847 & 3,2699 & 0,5483 & 1,6465 & 2,4867 \\
\hline$R \& D E$ & 0,0501 & 0,0231 & 0,0003 & 0,3345 & 0,0721 & 2,3059 & 5,1081 \\
\hline ESG & 46,4407 & 48,7603 & 11,1570 & 64,4628 & 12,6595 & $-1,1650$ & 0,8445 \\
\hline $\operatorname{LnA}$ & 9,9053 & 9,9673 & 7,0018 & 14,2963 & 1,5350 & 0,5678 & 0,4713 \\
\hline Age & 78,2456 & 66,0000 & 4,0000 & 347,0000 & 69,4358 & 1,6309 & 3,7551 \\
\hline Lev & 4,4665 & 2,5522 & 1,4604 & 42,8431 & 6,2698 & 4,7886 & 24,7469 \\
\hline ROI & 6,6070 & 9,0679 & $-25,5433$ & 26,1521 & 9,2635 & $-1,6107$ & 3,5916 \\
\hline PD_5Y & 0,0163 & 0,0117 & 0,0014 & 0,0844 & 0,0146 & 2,0738 & 6,3966 \\
\hline \multicolumn{8}{|l|}{2013} \\
\hline Tobin'sQ & 1,5363 & 1,4355 & 0,8200 & 3,1115 & 0,5369 & 1,1962 & 0,9611 \\
\hline $\mathrm{R} \& \mathrm{DE}$ & 0,0504 & 0,0248 & 0,0004 & 0,3463 & 0,0718 & 2,3201 & 5,4324 \\
\hline ESG & 48,9418 & 49,5868 & 25,2066 & 64,0496 & 8,2197 & $-0,5943$ & 0,1983 \\
\hline $\operatorname{Ln} A$ & 9,9132 & 9,8338 & 7,1368 & 14,2334 & 1,5022 & 0,6126 & 0,5139 \\
\hline Age & 79,2456 & 67,0000 & 5,0000 & 348,0000 & 69,4358 & 1,6309 & 3,7551 \\
\hline Lev & 4,2849 & 2,5968 & 1,3869 & 40,0434 & 5,8713 & 4,8062 & 24,6456 \\
\hline ROI & 7,6249 & 9,0063 & $-9,7118$ & 21,1601 & 6,2620 & $-0,5361$ & 0,4102 \\
\hline PD_5Y & 0,0097 & 0,0070 & 0,0013 & 0,0439 & 0,0085 & 2,0428 & 4,5716 \\
\hline \multicolumn{8}{|l|}{2014} \\
\hline Tobin'sQ & 1,5453 & 1,3956 & 0,7591 & 3,5594 & 0,5809 & 1,4263 & 1,8126 \\
\hline$R \& D E$ & 0,0511 & 0,0229 & 0,0008 & 0,4310 & 0,0785 & 2,7706 & 8,9362 \\
\hline ESG & 49,8893 & 50,8264 & 24,7934 & 63,2231 & 7,8641 & $-0,7566$ & 0,7977 \\
\hline $\operatorname{LnA}$ & 9,9661 & 9,8286 & 7,1999 & 14,2786 & 1,4569 & 0,7282 & 0,8051 \\
\hline Age & 80,2456 & 68,0000 & 6,0000 & 349,0000 & 69,4358 & 1,6309 & 3,7551 \\
\hline Lev & 4,0982 & 2,5439 & 1,4695 & 35,9302 & 5,3733 & 4,6375 & 22,7070 \\
\hline ROI & 7,6650 & 7,9780 & $-7,6378$ & 21,6907 & 5,7873 & 0,0070 & 0,7640 \\
\hline PD_5Y & 0,0100 & 0,0076 & 0,0009 & 0,0353 & 0,0080 & 1,4571 & 1,8761 \\
\hline \multicolumn{8}{|l|}{2015} \\
\hline Tobin'sQ & 1,6151 & 1,4632 & 0,7624 & 3,4175 & 0,6089 & 1,1441 & 0,6509 \\
\hline $\mathrm{R} \& \mathrm{DE}$ & 0,0501 & 0,0234 & 0,0004 & 0,3962 & 0,0736 & 2,6553 & 8,0865 \\
\hline ESG & 50,3075 & 50,4132 & 11,9835 & 62,8099 & 8,3874 & $-1,7490$ & 6,1028 \\
\hline $\operatorname{LnA}$ & 10,0421 & 9,9786 & 7,4688 & 14,2403 & 1,4032 & 0,7648 & 0,9772 \\
\hline Age & 81,2456 & 69,0000 & 7,0000 & 350,0000 & 69,4358 & 1,6309 & 3,7551 \\
\hline Lev & 4,1124 & 2,6334 & 1,5014 & 32,4158 & 5,1077 & 4,1691 & 18,1000 \\
\hline ROI & 7,9010 & 7,1101 & $-11,1749$ & 25,5760 & 6,4347 & 0,0107 & 0,8630 \\
\hline PD_5Y & 0,0124 & 0,0109 & 0,0022 & 0,0723 & 0,0105 & 3,5929 & 16,9449 \\
\hline \multicolumn{8}{|l|}{2016} \\
\hline Tobin'sQ & 1,5688 & 1,4448 & 0,9002 & 3,0942 & 0,5520 & 1,3055 & 1,1876 \\
\hline
\end{tabular}




\begin{tabular}{crrrrrrr} 
R\&DE & 0,0488 & 0,0256 & 0,0004 & 0,3659 & 0,0693 & 2,4810 & 7,0051 \\
ESG & 49,9955 & 49,5868 & 12,8099 & 66,1157 & 8,3879 & $-1,4772$ & 5,3800 \\
LnA & 10,1207 & 10,0297 & 7,6113 & 14,2370 & 1,3886 & 0,8114 & 0,9365 \\
Age & 82,2456 & 70,0000 & 8,0000 & 351,0000 & 69,4358 & 1,6309 & 3,7551 \\
Lev & 4,2013 & 2,6081 & 1,4411 & 29,5836 & 5,1579 & 3,7278 & 13,4392 \\
ROI & 8,6719 & 7,9791 & $-8,1858$ & 27,8623 & 5,8871 & 0,4050 & 1,5146 \\
PD_5Y & 0,0119 & 0,0094 & 0,0023 & 0,0407 & 0,0091 & 1,6998 & 2,2190 \\
\hline
\end{tabular}

Table 5

Correlation Matrix

\begin{tabular}{|c|c|c|c|c|c|c|c|c|}
\hline $\begin{array}{l}\text { Correlation } \\
\text { Probability } \\
\end{array}$ & TOBIN'SQ & AGE & ESG & R\&DE & LEV & LNA & PD_5Y & ROI \\
\hline TOBIN'SQ & $\begin{array}{l}1 \\
-\end{array}$ & & & & & & & \\
\hline AGE & $\begin{array}{c}-0,2193 \\
0,0002\end{array}$ & $\begin{array}{l}1 \\
-\end{array}$ & & & & & & \\
\hline ESG & $\begin{array}{c}-0,1463 \\
0,0134\end{array}$ & $\begin{array}{l}0,0842 \\
0,1564\end{array}$ & $\begin{array}{l}1 \\
-\end{array}$ & & & & & \\
\hline R\&DE & $\begin{array}{l}0,2527 \\
0,0000\end{array}$ & $\begin{array}{c}-0,1841 \\
0,0018\end{array}$ & $\begin{array}{c}-0,1010 \\
0,0888\end{array}$ & $\begin{array}{l}1 \\
-\end{array}$ & & & & \\
\hline LEV & $\begin{array}{c}-0,2956 \\
0,0000\end{array}$ & $\begin{array}{l}0,1353 \\
0,0223\end{array}$ & $\begin{array}{l}0,0621 \\
0,2961\end{array}$ & $\begin{array}{c}-0,2042 \\
0,0005\end{array}$ & $\begin{array}{l}1 \\
-\end{array}$ & & & \\
\hline LNA & $\begin{array}{c}-0,4146 \\
0,0000\end{array}$ & $\begin{array}{l}0,1678 \\
0,0045\end{array}$ & $\begin{array}{l}0,3760 \\
0,0000\end{array}$ & $\begin{array}{c}-0,4133 \\
0,0000\end{array}$ & $\begin{array}{l}0,6114 \\
0,0000\end{array}$ & $\begin{array}{l}1 \\
-\end{array}$ & & \\
\hline PD_5Y & $\begin{array}{l}-0,5587 \\
0,0000\end{array}$ & $\begin{array}{c}-0,1252 \\
0,0347\end{array}$ & $\begin{array}{l}0,0684 \\
0,2494\end{array}$ & $\begin{array}{l}-0,1549 \\
0,0088\end{array}$ & $\begin{array}{l}0,5104 \\
0,0000\end{array}$ & $\begin{array}{c}-0,4194 \\
0,0000\end{array}$ & $\begin{array}{l}1 \\
-\end{array}$ & \\
\hline ROI & $\begin{array}{l}0,5168 \\
0,0000\end{array}$ & $\begin{array}{c}-0,2046 \\
0,0005\end{array}$ & $\begin{array}{r}-0,0718 \\
0,2266\end{array}$ & $\begin{array}{l}0,0122 \\
0,8379\end{array}$ & $\begin{array}{c}-0,1626 \\
0,0059\end{array}$ & $\begin{array}{c}-0,2695 \\
0,0000\end{array}$ & $\begin{array}{c}-0,5420 \\
0,0000\end{array}$ & $\begin{array}{l}1 \\
- \\
\end{array}$ \\
\hline
\end{tabular}

Table 6

Multiple regression results

\begin{tabular}{|c|c|c|c|c|c|c|}
\hline & Coefficient & Std.Error & $t$ & p-value & & VIF \\
\hline const & 2,23647 & 0,232524 & 9,6183 & $<0,0001$ & $* * *$ & \\
\hline$R \& D E$ & 0,996165 & 0,54256 & 1,8360 & 0,0674 & $*$ & 1,276 \\
\hline ESG & $-0,00177063$ & 0,00329611 & $-0,5372$ & 0,5916 & & 1,243 \\
\hline LnA & $-0,0602003$ & 0,0246377 & $-2,4434$ & 0,0152 & $* *$ & 2,405 \\
\hline Age & $-0,00061478$ & 0,000206612 & $-2,9755$ & 0,0032 & $* * *$ & 1,093 \\
\hline Lev & 0,00564398 & 0,00607821 & 0,9286 & 0,3539 & & 2,037 \\
\hline ROI & 0,0233616 & 0,00435029 & 5,3701 & $<0,0001$ & $* * *$ & 1,576 \\
\hline PD_5Y & $-18,03$ & 4,88419 & $-3,6915$ & 0,0003 & $* * *$ & 1,933 \\
\hline R-squared & \multicolumn{2}{|c|}{0,435244} & & & & \\
\hline Adjusted R-squared & \multicolumn{2}{|c|}{0,420972} & & & & \\
\hline P-value(F) & \multicolumn{2}{|c|}{$9,46 \times 10^{-24}$} & & & & \\
\hline Akaike & \multicolumn{2}{|c|}{336,6940} & & & & \\
\hline
\end{tabular}

$*, * *, * * *$ indicate significance at the $0.10,0.05$ and 0.01 levels, respectively 
